\title{
Seroprevalence of influenza A (H9N2) virus infection among humans in China: A meta-analysis
}

\author{
Yanping $\mathrm{Qi}^{1}$, Hong-Bo Ni${ }^{2}$, Weina Guo ${ }^{1}$, Chang Liu ${ }^{1}$, Xuelong CHEN ${ }^{1}$, Shenghe $\mathrm{Li}^{1}$, and \\ Wenchao $\mathrm{Li}^{1}$ \\ ${ }^{1}$ Anhui Science and Technology University \\ ${ }^{2}$ Qingdao Agricultural University
}

April 28, 2020

\begin{abstract}
In order to fully evaluate the seroprevalence and risk factor of avian influenza A (H9N2) virus infection among humans in China, a systematic review and meta-analysis was performed. The literature on the seroprevalence of human H9N2 infection in China was searched from inception to March 20, 2020 in English and Chinese databases, including PubMed, Clinical Trial, VIP, CNKI and databases. Duplicated literature, and literature with incomplete data were excluded, leaving the results from 41 studies on H9N2 infection among humans in China being analyzed quantitatively by meta-analysis. A total of 41 studies (including data of 47,743 humans) met the inclusion criteria. In China, the overall seroprevalence of H9N2 infection among humans was $4.10 \%(95 \% \mathrm{CI}=3.20-5.07)$, while in those from north China the prevalence was $5.94 \%(95 \% \mathrm{CI}=4.75-7.13)$, greater than in other regions of China. The seroprevalence of H9N2 infections was associated with test method, sampling time, gender and demographic characteristics of the groups. This review clearly indicates that the risk factors for H9N2 infection varies with multiple factors. Thus, further research is needed on how to formulate specific measures to minimize the emergence and transmission of influenza virus.
\end{abstract}

\section{Hosted file}

Manuscript-TED . doc available at https ://authorea . com/users/314187/articles/444542-seroprevalenceof-influenza-a-h9n2-virus-infection-among-humans-in-china-a-meta-analysis

\section{Hosted file}

Table 1.xlsx available at https://authorea.com/users/314187/articles/444542-seroprevalence-ofinfluenza-a-h9n2-virus-infection-among-humans-in-china-a-meta-analysis

\section{Hosted file}

Table 2.xlsx available at https://authorea.com/users/314187/articles/444542-seroprevalence-ofinfluenza-a-h9n2-virus-infection-among-humans-in-china-a-meta-analysis 

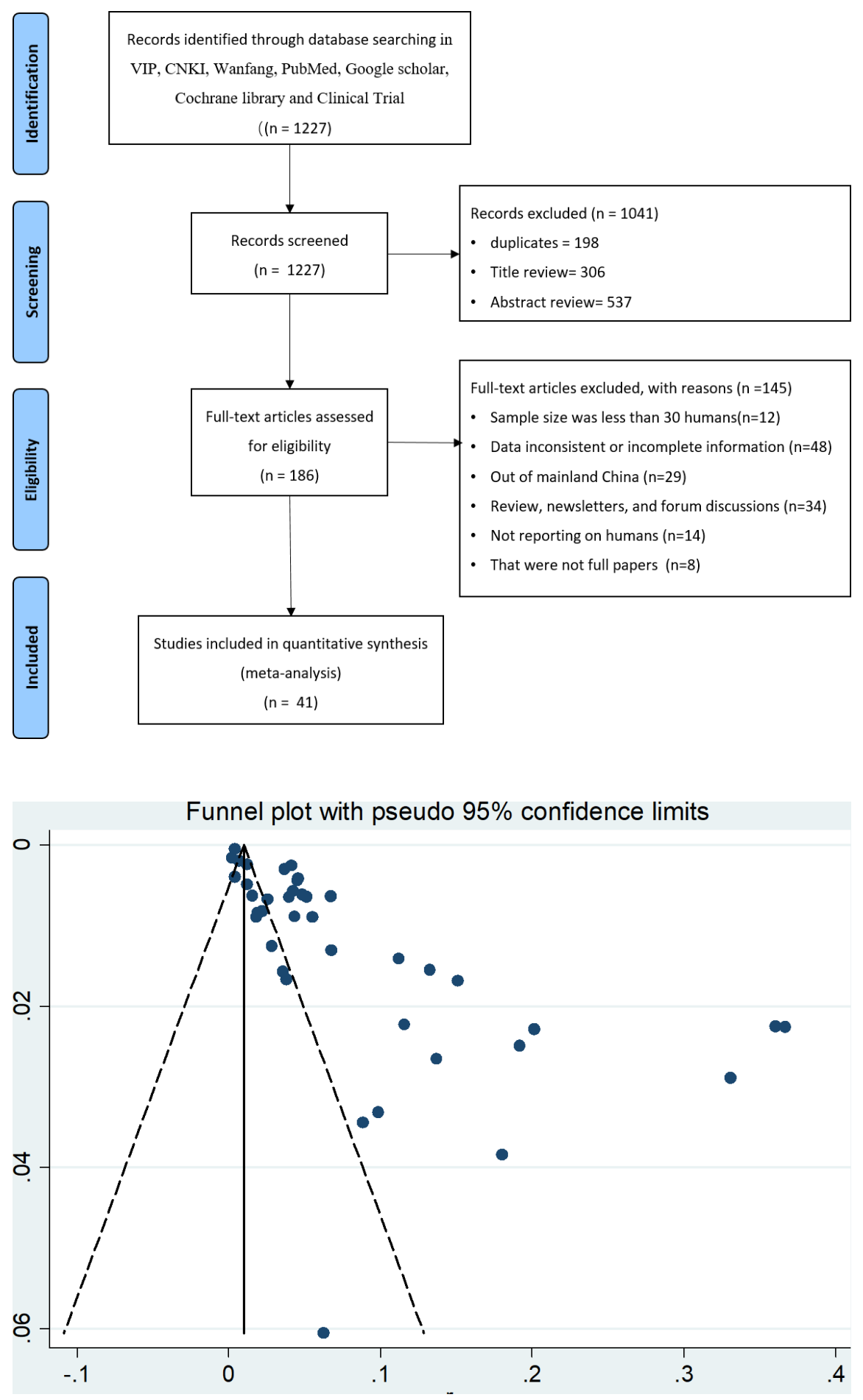


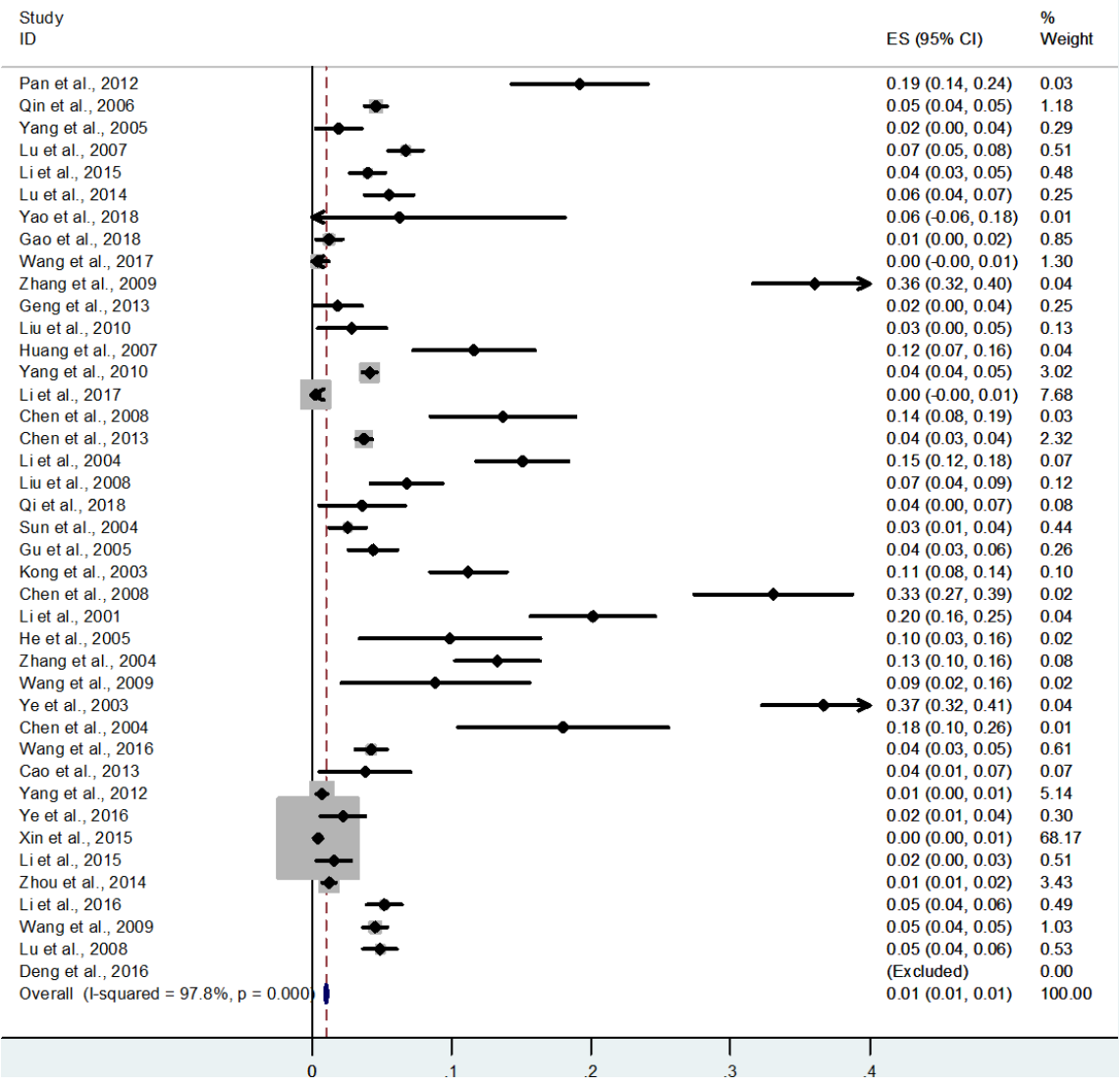




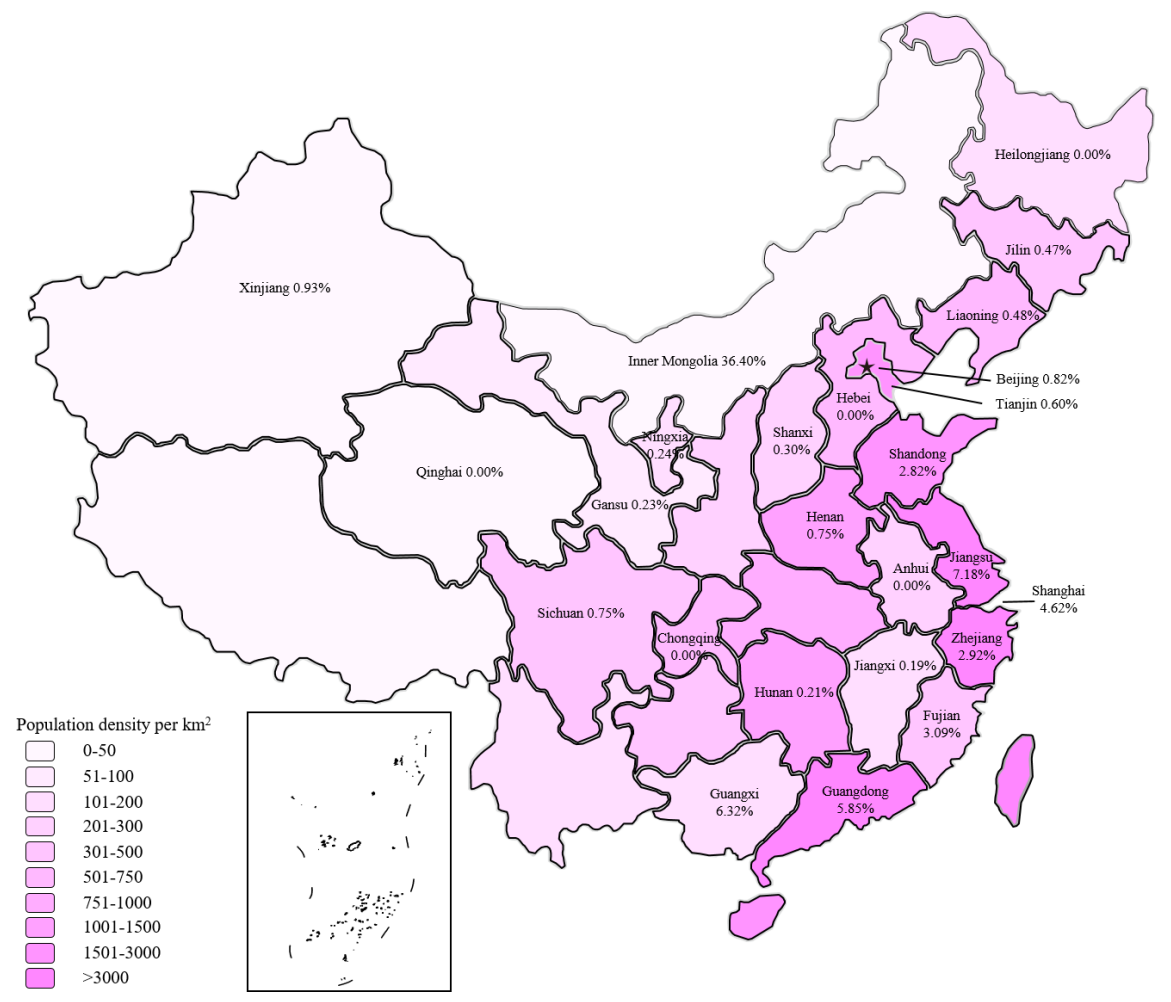

